Journal of Business and Tourism

Volume 04 Number 02

July-December, 2018

\title{
Impact of Firm Characteristics on IPO's Short Run Performance: Evidence from Pakistan
}

\author{
KAMRAN FAROOQ \\ Institute of Business Studies and Leadership \\ Abdul Wali Khan University Mardan, Pakistan \\ kamranfarooq386@gmail.com \\ SAEED AKBAR \\ Demonstrator, Institute of Business Studies and Leadership \\ Abdul Wali Khan University Mardan, Pakistan \\ saeed.akbar@awkum.edu.pk \\ KIRAN ALIM \\ Faculty of Management \\ Universiti Teknologi Malaysia (UTM), Skudai, Malaysia \\ alimkirn00@gmail.com \\ SOURATH \\ PhD Scholar, Institute of Business Studies and Leadership \\ Abdul Wali Khan University, Mardan
}

\begin{abstract}
In present day world, the concept of initial public offering (IPO's) has got much significance since its execution altogether influence the success of the companies. The current study aims at conducting a nonsystematic review of literatures on the concept of short runs performance of initial public offering in Pakistan. In this regard, we studied the IPO's of 77 companies listed at Pakistan Stock Exchange (PSX) from the period of 2000-2015. The finding shows a positive and significance relationship between size of the firm and underwriter reputation while the age of the firm and risk shows negative relationship with the dependent variable MAAR. The performance of initial public offerings has significant effect on success or failure of a company. In this way, the companies in modern corporate world can ensure their success through effective utilization of initial public offerings.
\end{abstract}

Keywords: $\quad$ IPO's short run performance, firm size, MAAR, firm Age, IPO risk and Underwriter Reputation

\section{Introduction}

Aninitial public offering (IPO) occurs whensecurity or stock of a private company is offer for sale topublic market for the first time. The issued occur when the firm decides to go public and to generate an immediate equity to finance their operations or to pay the existing debt by issuing security to public on cash offer. The company IPO's success and failure is highly associated with the IPO's after market price performance and setting the 
correct offering price is difficult for the firm's underwriter. If the price is set too low or too high it will cause a potential cost.When the IPO's is issued to publicit istoo risky and potential investors are not willing to purchase risky venture at high price. So, the companies underprice their security by lowering their price from fair market value which helps the company to sell the IPO's in the initial days of trading. The phenomenon at which the IPO's is sold lower from its fair market price is an underpricing of IPO's.

Ibbotson and Ritter et al. (1988)stated that underpricing is common phenomena and linkedwith the companies stipulating IPO's. Underpricing isdefined as the difference between the first day offering price and closing price of the security.Shehzad Khan et al. (2016) stated the IPO short run performance is linked with most of the financial markets in the globe. But the magnitude of the underpricing of an IPO's is different in every country depend on the institutional structure, Rule regulation and the characteristics of the company going to public.

The reason why companies do IPO's for generating equity to finance their operation instead of taking loan from financial institution. Generally, on loan or debt the companies will pay interest and on equity the companies will pay the earning per share. That's why initially the companies start their operation by generating funds from private potential investors or banks. When a firm grow up and known to the potential investor or recognize in the market and company need more funds, so they decide to 'go public' by issuing securities to public. The main reason behind 'going to public' is to better liquidity and generate funds from diversified investors. Initial public offering (IPO's) isissued at any time in the life of the company. IPO's are issued when the company decides to go public for the very first time. If the stock of the company is issued to public for the 2 nd time it is known as season issue. The price of season IPO's is always high from first time issued IPO's because season IPO's are more secure from the initial.

The purpose of this study is to examine the firm short run IPO's performance and some pertinent theories of IPO's underpricing in Pakistan. Some of the researcher have explain the behavior of the short run IPO's performance. According to Reilly and Hatfield (1969) and Logue (1973) they were the earlier researchers stated that on average IPO's generate high abnormal initial return in the short run. The behavior is due to low price of an IPO's from market price or underpricing and subsequently the price will go up in the short run. In Pakistan,most of the companies goes public and issued their stock. Sometime boost of issuing of IPO's from many companies occur which (fluctuate the PSX-100 index) due to uncertainty and as result of high-risk high return.Also, to study pertinent theories of IPO's underpricing like Ex-ante uncertainty theory,Signaling theory andUnderwriter reputation theory.

\subsection{Problem Statement}

In this competitive world, every firm is trying to take competitive edge in market and grow up in the market by increasing production and bringing innovations in the product line. But it needs sufficient amount offunds to remain alive in the competition while they usually face financial problems.To finance their operations, they generate equity by issuing the IPO's. The problem arises when some character of the firm affects the short run performance. In short run, they face the problem of underpricing which affect the short run performance of IPO. 


\subsection{Research Questions}

The research questions are as under:

1. How firm characteristics influence the IPO's short run performance in Pakistan?

2. Whether and how IPO's theories are pertinent in Pakistan?

\subsection{Objectives}

The specific objectives of the study are

- To examine the impact of firm characteristics on IPO's short run performance in Pakistan.

- To examine the pertinent theories of IPO's underpricing in Pakistan.

\subsection{Significance of the Study}

This study will give guidelines to investors to enhance their understanding of the short run performance of IPO's in Pakistan. This would also assist the investors in making viable decisions while investing in the stock market. The firms will be able to appreciate the fundamentals of underpricing and short run performance of IPOs and this would assist them in decisions making while floating their shares in public through in the shape of IPO's. They would be able to make viable decisions in setting the offer price of shares during IPOs. The research would provide useful information to future researchers who want to advance the knowledge and literature of underpricing of IPO's.

\section{Literature Review}

A lot of studies were organized to explore the short-run performance of IPO's. The researchers expressed in their paper that normallyIPO'sgive initial positive return in short-run. Ibbotson's (1975) studied 120 IPO'sduring 1965-69 of USA market and finds positive initial return andshows average initial return of $11.4 \%$ on first month after the issue date. Jaffe et al. (1975) use a large sample of IPO's for similar period and average initial return was reported $16.8 \%$. Shehzad Khan et al (2014) stated that the first daypositive return and negative return of IPO's in long-run has continue to exist problem for academicians and potential investor from previous 30 years. It's derived from review of previous literature's that the occurrenceof IPO's underpricing's in the short-term and under performance in the long-run present in every financials' market in all over the world. While the extent of return depends on the market's conditionsand varies from country to country.

Ritter et al.(1988) studied 8668 IPO's during 1960 to 1987 and file positive initial return of IPO's and investigate 16.4\% Average initial returns. Loughran's et al. (1994) reveal from 28 countriesthe significant underpricing and short-run extra returnalso argues that in every country with a stock market has found short-run underpricing.Dimson (1979), studied United Kingdom marketand reported $8.50 \%$ to $17 \%$ initial returns. Ritter in (1984), studied more than 5000.00IPO'sform's 1960 to 1982 and investigate initial returns of $18.80 \%$ which is over from the offering prices soon after trading started. Sohail et al. (2007) examine the short-term performance of about 50 IPO'sfrom 2000 to 2006listed on Karachi stock exchange. They discover an average underpricing of $35.660 \%$ and average market Adjusted Copulative's Abnormal returns (ACAR) from one year since listing are $-19.6 \%$ by use of Market Adjusted Model (MAM) and are $-53.3 \%$ which have the negativesignificant level of 0.05 . Theyexplain the level of underpricing of Pakistani IPO's also use a Cross Sectional data analysis and founds the level of underpricing which is determined byoffer size, Ex-ante uncertainty and oversubscription 
variables. In Malaysian IPO's market, the underpricing is examined by Uzakiet al. (2012) by utilizing about 476.0IPO'sfrom 2000-11, and finds the presence of $35.8 \%$ underpricing and the factor which affect IPO underpricing. Adjasi et al. (2011) they studied the underpricing of about 77 NigeriansIPO's 1990 to 2006 and file the InitialsAbnormal Returns (IAR) of $43.1 \%$. They found important variables in determining IPO's underpricing such as size of a company and audit quality. Kiymaz in (2000) originate underpricing of $13.60 \%$ by studying the specimen of Turkish IPO's 1990 to 1995 . Mcguinness. (1992) studied 80 Hong Kong IPO'sfrom1980 to 1990. The study of post listing returns for the IPO'sshows that significant positive returns on the first day of trading and disappear thereafter. Analysis of initial excess market returns reveals underpricing of approximately 18\%.Sohailet al.(2007) investigate the short-term performance of 50 Pakistani IPO's during 2000-06 and reported on average underpricing of $35.6 \%$. They also found that degree of underpricing affected by over subscription, Size of offer, Ex-ante uncertainty and market capitalizations.

Sohail \&Rehman (2010) both studied the short-term performance of 73 Pakistani IPO's during 2000-09 and deliberate underpricing on the first, $5^{\text {th }}, 10^{\text {th }}, 15^{\text {th }}$ and $20^{\text {th }}$ trading day. They also reported underpricing in a range of $37 \%$ to $42 \%$ from $1^{\text {st }}$ to $20^{\text {th }}$ trading day.RamazannAktas et al. (2003) the recent research on IPO's also investigate some factors that are linked with the levels of short run underpricing. Some are the followingissued features are size of firm,market trend, offer size, banker reputations, stock price range etc. The study was organized to establish modelwhich depends on these visages to predict the short-run performance of IPO'sin Stock ExchangeIstanbul. They analyze the IPO'sin Turkish Stock Market from 1992 to 2000 by using of 95.0IPO'swithin 1992 to 1996 build the model and 95.0IPO'sduring the following 1997 to 2000 to test our models. Prior to build the foretell models, they investigate the factors that can differentiate b/w high and low short-run IPO's return.Borges (2007) in his paper report initial underpricing of $11.1 \%$ in Portugueses IPO's general Market. Kucukkocaoglus (2008) says that short-term underpricing was higher when the underwriters used fix offer and books building method. Hefiles the underpricing of an IPO's on first month 14.1 \%and first day was 11.7\%.Mumtaz et al.(2016) studied whether IPO'sare underpriced hasapremise of strangeness for education and professionals for some period. The prior research has provided proof in favor of underpricing which is exists in the entire globe. To better explain IPO's underpricing, some theories are discussed below.

\subsection{Theories}

The following theories used in the research to support andexplain research topic effectively.

\subsubsection{Signaling Theory}

Allenet al. (1989) structure a model which clarifies the underpricing of IPOs by methods for signaling of the issuing firm. This flagging model contains two different sorts of companies'low-quality companies and high-quality companies. They accept that the prospect of the companies is best known by the company itself. They clarify that commendable company, with fine prospects, trying to signal potential speculators about their great prospects. They can also signal to their investors by setting IPOs price lower. According to Welch (1979)a company with bad prospects does not have in a condition to 
underprice their security because they are not able to bear the loss come from IPOs underpricing. Ibbotson (1975), stated that when the IPOs are underpriced so it through a good taste in the mouth of potential investors. This good taste worries the issuing company about the uncertainty that the prices of future IPOs will be decrease so they sell the present IPOs an attractive price to save their self. Fabrizio (2000) argues that it doesn't mean that uncertainty about the firm is eliminated but it does increase the chances that a company gets examine as good companiesby investors. So, most of the firm underprices their IPOs to increases the chances that potential investors will think positive about the future of the firm and to increase the chances of occurring that aseasoned equity offering can be issued at better rates. A SEO is a newly equity issues of a firm which is already publicly traded.

\subsubsection{Underwriter Reputation Theory}

Many issuing firms hire underwriter for pricing process and pricing decision of the security or stock. A small number of firms will process the IPO's by themselves. The under-writer has betterinformationof prices in capital market than the issuing companies. Because the issuers of the security not totally measured the efforts of the hire underwriter, underwriters can underprice the IPO'sthat's why they sell the security more easily to the capital market. Booth et al.(1986),Manasteret al.(1990), Truemanet al. (1986) define that the better way to diminish information asymmetry is to hirea reputable underwriter having greater market access to information and large market share. The empirical result of underwriter reputation is mixed. Some researcher like Carter et al. (1990) and Beatty \& Welch (1996) shows that between underpricing and underwriter reputation there is positive relationship. But according to Ritter and Lin (2011) and Hoberg (2007), there is negative relationship between underpricingof IPO's and underwriter reputation.

\subsubsection{Ex-ante Uncertainty}

Ritteret al. (1986.) stated in their paper about valuation of IPO's in the secondary market and initial return is subjected to pre-market uncertainty. The greater the level Ex-ante uncertainty the greater will be the level of underpricing. As more investor in the market informed about valuation then there will be more uncertainty which will to higher underpricing. Beatty and Ritter (1986) used two proxies to measure the premarket uncertainty and the result comes from it recommend that there is positive association between initial return and pre-market uncertainty.Many researchers tested ex-ante uncertainty theory by using different variables such as issuing specific characteristics, companies specific characteristics and prospectus information disclosure for ex-ante uncertainty. James and Wier (1990), Hamaoet al. (2000), the researcher Habib and the other Ljungqvist(2001) used firm age and size as proxy for Ex-ante uncertainty and demonstrated positive association between firm characteristics and underpricing. The relation comes from some other researcher by using the same variable. The hypothesis of ex-ante uncertainty has established remarkable empirical support as majority of the asymmetric information theories of IPO underpricing found positive association betweenunderpricing and Ex-ante uncertainty. 


\subsection{Hypothesis Development}

Some important variables are identified to investigate their impact of underpricing of IPOs in Pakistan. All these variables affect the level of underpricing in Pakistani, IPO's. These variables are chosen from various Research papers i.e. Shehzad Khan(2017), Khalid Sohail and Nasr (2009), Atif Kifayatet al.(2014),inwhich only one is dependentvariable which is Market adjusted abnormal returns (MAAR). These hypotheses arebrieflyexamined with the use of these variables.

\subsubsection{Age}

The independent variable age of the firm shows history of operating activity from the start. The firms which are operating from long time have more information available to the public in the form of annual reports as compared to the information available of new companies. The old firmsdecrease the problem ofEx-ante uncertainty and reduce underpricing. The researcher also proved that the mature companies have less Ex-ante uncertainty as compared to the newly emerge companies which shows negative association between underpricing and Age of the company. But some researchers like Ritter et al., Agathee et al. (2012), Bilson et al. (2003), Nielsson and Wojick(2016). Shows positive relation between 'Age' and underpricing by arguing that older companies underprice their IPO's to attract the potential customers like younger companies. In Pakistan, due to information asymmetry the presence of ex-ante uncertainty the researchers show negative relation between 'Age' and underpricing by arguing that older firms are less underpriced and have less uncertainty from the younger firms. Therefore, there are negative association between IPO's short-run performance in Pakistan and 'Age' of the company.

$\mathbf{H}_{1}$ : There is a negative association between IPO's short-run performance and 'Age' of the companyin Pakistan.

\subsubsection{Size}

Company size in this research is used as independent variable. Company sizeshows trust of investor. According to Beatty and Ritter (1986), larger firms are less risky and have less ex-ante uncertainty due to which they can easily raise huge funds by going public. Therefore, potential investors are always feeling confident by investing in the larger firms. Based on the Ex-ante uncertainty researchers Ibbotson et al. (1994) and Carter et al (1998), Suchard and Singh (2007), have study the effect of 'Size' and underpricing find negative relationships between the level of underpricing and Size of the firm. Alli et al. (2010), Marisetty and Subrahmanyam (2010) shows positive relationship between these two variables by argues that large size of firm underprices their IPO, $\mathrm{s}$ all the globe to attract the investors.

In Pakistan (Sohail and Nasr, 2007; Mumtaz and Ahmad, 2014) show negative relation in the two variables based on ex-ante uncertainty that larger firm less underprice their IPO's in short run because of low ex-ante uncertainty. Therefore, the result shows negative association between underpricing and company Size.

$\mathbf{H}_{\mathbf{2}}$ :There is a negative association between underpricing and company Size in Pakistan.

\subsubsection{IPO Risk}

'Risk' is use as an independent variable in this model. It is defined as the after-market Standard deviation base on the initial twenty days IPO's return excluding the initial return". Ritter (1984), argue that when the riskier firm decides to go public then they 
have more underpricing and high uncertainty level which show positive relationship between IPO 'Risk' level and the expected initial returns. In Pakistan, several studies show significant positive relationship between IPO Risk and underpricing. The researchers (Sohail and Nasr 2007; Mumtaz and Ahmad, 2014) and some other elaborated the IPO 'Risk' is prime factors in determining IPO underpricing. Furthermore, the Ritter (1984) finally suggested positive association between underpricing and IPO Risk followed by IPO high volume.

$\mathbf{H}_{3}$ : There is a positive association between underpricing and IPO's Risk in Pakistan.

\subsubsection{Underwriter Reputation}

Itis another independent variable used in this research and is defined as a person or investment bank who helps the firms to set price of IPO's and sell them into market with effective strategy and take a risk if the securities are not sold in the market the underwriteritself purchase the IPO's with less price.Ritteret al. (1984), Brooks et al. (2008), found positive association between underpricing and underwriter reputation. By argue that underwriters have more information related to the market and underprice IPO's to maximize their on-profit regard less of gross proceeds.Beatty and Ritter (1986), Carter and Manaster (1990), says that well known underwriters are attached with the lowers underpricing to maintain theirs good reputation in the markets and the reputable underwriter carry out only good quality IPO to retain their high reputation in the market. The researchers (Carters and Manaster,1990;Mudambiet al., 2012)examined total effect of underwriter on short run performance of IPO's and find negative relationship by arguing that high reputable underwriteris link with low category of underpricing.

In Pakistani IPO's the researcher show positive association between underpricing and underwriters' reputations and says that underwriter saves their self by underpricing the IPO's to efficiently sellin the public market to earn profits regardless of firm gross proceeds. So, the study confirms that there is positive association between the short-run IPO's of underpricing and underwriter reputation.

$\mathbf{H}_{4}$ : There is a positive association between the short-run underpricing of IPO's and underwriter reputation.

\section{Methodology}

This section is all about the methodology of this study. It contains research design to be used in the study, sample size and sampling method,data collection, descriptive statistics and analysis methods and tools.

\subsection{Research Design}

This study investigated performance of theshort run IPO's and IPO's Underpricing in Pakistan. A Descriptive Research design is use in the research. The descriptive research is the process of collection of data to investigate the hypothesis or answer concerning questions about thestatus of the subject study. This method was selected to meet the objectives of the studyandenables the researchers.

\subsection{Sources of Data Collection}

This research is totally relay on Secondary data and all the data is collected from the period 2000 to 2015 on studying the IPO's of 77 companies which is listed on the Pakistan stock exchange (PSX). 


\subsection{Population and Sample}

\subsubsection{Population}

Population of the study isconsisting of all the firms' data that have gone public from 2000 to 2015. The data set used in this study is comprised of all companies IPOs listed on the Pakistan Stock Exchange (PSX).

\subsubsection{Sample}

The sample data has been gathered from secondary sources. The sample size consists of the IPO's of77 companieswhich are listed on Pakistan stock exchange(PSX).

\subsection{Research Variables and Their Measurement}

\begin{tabular}{|c|c|c|}
\hline Variable & $\begin{array}{c}\text { Measurement } \\
\text { Dependent Variables }\end{array}$ & Sources \\
\hline LNMAAR & $\begin{array}{l}\text { Market Adjusted Abnormal Returns } \\
\text { variable is used the only dependent } \\
\text { variable in the research and it is the total } \\
\text { amount of money left on the table is } \\
\text { computed through by MAAR. } \\
\text { LNMAAR }_{\mathbf{x}, \mathbf{d}}=100 \times\left\{\left[\frac{\left(1+R_{x, d}\right)}{\left(1+R_{r, s}\right)}-1\right]\right\}\end{array}$ & $\begin{array}{l}\text { McDonald and Fisher } \\
\text { (1972), Aggarwal et al. } \\
\text { (1993), Affleck-Graves } \\
\text { et al.. (1996). Su and } \\
\text { Fleisher (1999). }\end{array}$ \\
\hline Age of the firm & $\begin{array}{l}\text { Independent Variable } \\
\text { Company age is determined inseveral } \\
\text { years from the date of adding to the date of } \\
\text { listing in the stock exchange. The age in } \\
\text { number of year is then expressed is the } \\
\text { logarithms of one plus the company age. }\end{array}$ & $\begin{array}{l}\text { Loughran and Ritter } \\
(2004) \text {, Megginson and } \\
\text { Weisss (1991), } \\
\text { Hamaoet al. (2000), } \\
\text { Habib and Ljungqvist } \\
\text { (2001), Wasserfallen } \\
\text { and Wittleder (1994), } \\
\text { Carter and Manaster } \\
\text { (1990). }\end{array}$ \\
\hline Size of the firm & $\begin{array}{l}\text { Size of the company is measured as a } \\
\text { natural logarithm of gross proceeds. } \\
\text { Whereas gross proceeds are measure by } \\
\text { total number of offered shares multiplied } \\
\text { by the offer size. }\end{array}$ & $\begin{array}{l}\text { Corwin and Harris } \\
(2001) \text {, Hamaoet al. } \\
(2000) \text {, Megsginson } \\
\text { And Weiss (1991), } \\
\text { Wasserfallen and } \\
\text { Wittleder (1994), } \\
\text { Habib and Ljungqvist } \\
(2001) \text {. }\end{array}$ \\
\hline Post IPO’s Risk & $\begin{array}{l}\text { Post IPO risk is calculated through after- } \\
\text { market Standard Deviations (SD) rely on } \\
\text { the initial 20- days return excluding the } \\
\text { firstly return. }\end{array}$ & $\begin{array}{lr}\text { Beaulieu } & \text { and } \\
\text { MrissaBouden } & \text { (2015), } \\
\text { Ritter } & \text { (1984), } \\
\text { Agathee et al..(2012a), } \\
\text { Chiu (2008). }\end{array}$ \\
\hline $\begin{array}{l}\text { Underwriter } \\
\text { Reputation }\end{array}$ & $\begin{array}{l}\text { The underwriter reputation can be } \\
\text { computed by adding all the frequency of } \\
\text { IPO's and underwriters carry out and }\end{array}$ & $\begin{array}{l}\text { Kenourgios et al. } \\
\text { (2007), Mudambiet al.. } \\
\text { (2012), Hoberg (2007), }\end{array}$ \\
\hline
\end{tabular}




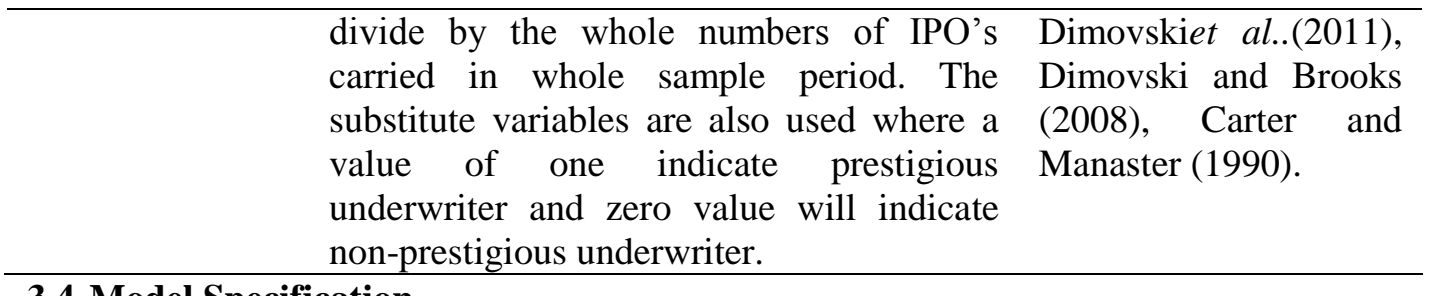

\subsection{Model Specification}

In this study, the model is estimated to test hypothesis. The independent variables used in the model are Firm Age, Firm Size, IPO's Risk and Underwriter Reputation.

$M A A R=\beta_{O}+\beta_{1}$ Age $+\beta_{2}$ Size $+\beta_{3}$ Risk $+\beta_{4} U D R+\varepsilon$

While

LnMAAR = Market adjusted abnormal Return.

Age $\quad=$ Age of the firm.

Size $\quad=\log$ of gross proceeds.

Ex-ante $\quad=$ Risk of IPO's.

UDR = Underwriter Reputation.

( $) \quad=$ The remaining component of the firm (error term).

$\beta_{O}=$ Constant coefficient (intercept),

$\beta_{1}, \beta_{2}, \beta_{3}, \beta_{4}=$ coefficients of independentVariable.

\section{Results and Discussion}

This chapter is all about the data interpretation and analysis. The results are accomplished in the following manner Table 4.1 shows the correlation matrix, Table 4.2 shows variance inflation factor Table 4.3 shows the results of White and Breusch-Pagan Test, Table 4.4 shows the descriptive statistics and Table 4.5 explain the Research Hypothesis test.

\subsection{Diagnostics test for Regression Analysis}

The study is based on quantitative analysis of secondary data.By using the following different models of regression. The data use for regressions model will fulfill the selected three basic assumptions.

\subsubsection{Collinearity}

The regression model is always exposed to theproblemof Collinearity. The main problem which is usually arises in all researches is multicollinearity. Multicollinearity issues is the resultof a highly strong correlations within the variable againstof the facts that no new information is added to regressions models. The regressions coefficients become inexplicit when-ever the variableis very highly correlated witheach other's and it becomes hard to assign the changes in the dependent variables toone or other of the explanatory variable. The researcher suggests the correlationswithin variables will not be more than $70.0 \%$. If more than $70.0 \%$ correlation exists so it indicates a multicollinearity problem.

To examine the collinearity among variablesof the current study use correlation matrix and variance inflations factor (V.I.F) analysis. The outcomesof correlations matrix of the whole variables are tabulated in the Table 4.1. The variables are, Market adjusted abnormal Return s (InMAAR), Age of the firm (Age), Size of the firm (Size), IPO's Risk (Risk),Underwriter Reputation (UDR). 
Table No 4.1: Correlations Matrix

\begin{tabular}{cccccc}
\hline & LnMAAR & Age & Size & Risk & UDR \\
\hline LnMAAR & 1.0 & & & & \\
\hline Age & -0.2432 & 1.0 & & & \\
\hline Size & 0.147378 & 0.298974 & 1.0 & & \\
\hline Risk & 0.033925 & -0.01451 & -0.01153 & 1.0 & 1.0 \\
\hline UDR & 0.351472 & 0.083241 & 0.003725 & 0.103575 &
\end{tabular}

This tabled present the pearson correlations coefficient in between variables with their significance. The variables are as Market adjusted abnormal Return s (LnMAAR), Age of the firm (Age), Size of the firm (Size), IPO's Risk (Risk), Underwriter Reputation (UDR).

The study also applied the important factor Variance Inflation Factor (VIF) to check the Collinearity amongst dependent and independent variables. When variance inflation factor value is more than from ' 10 ' indicatethe presence of multicollinearity problem. The table 4.2 provides the summary of (VIF) test resultsof the Model use to examine the IPO's short run performance. The result indicated that all the VIF values are less than ' 10 ' which mean that there is no multicollinearity exists among the variables. So, researchers can use the data for their analysis.

Table No 4.2: Variance Inflations factor

\begin{tabular}{cc}
\hline Variables & Model \\
\hline Age & 1.107 \\
Size & 1.099 \\
Risk & 1.011 \\
UDR & 1.019
\end{tabular}

The above table provides the results of Variance Inflation Factor (VIF) test of all the selected variable used in the model to examine the IPO's short run performance.

\subsubsection{Heteroscedasticity}

Their assumptions indicate that'serror terms have constant variance (i.e. Homoscedastic) for every observation. To clarify that there is no heteroscedasticity in the residual. This study applied two tests for nonexistence of heteroscedasticity in the data, Breusch-Pagan and White's decomposing test. The null hypothesis of "Heteroscedasticity is not present" and is tested as against the alternatives hypothesis $\mathbf{H}_{1}$ of "Heteroscedasticity". The result is tabulated in table 4.3. The p-values computed for both tests are greater than 0.050 , which indicate that data are homoscedastic which means that the error variance is constant and not suffers from heteroscedasticity problem and the data can be used.

Table No: 4.3 White and Breusch-Pagan Test

\begin{tabular}{lll}
\hline Test & Chi-Square & P-Value \\
\hline White test & 13 & 0.956366 \\
Breusch-Pagan test & 4 & 0.172191
\end{tabular}

The above table present the result of the conclusion of Heteroscedasticity's tests. These tests are performed with a use of built in command in theGretl software to test the nulls hypothesis of residuals are homoscedastic, against the alternate hypothesis of residuals are heteroscedastic. 


\subsubsection{Linearity}

The regressions model should be linear in parameters and not multiplied together, divided, cubedor square etc. To ensure the linear association amongst the dependent variables and the independent variable, the current study used natural logarithm to the values that are in days, years, ratios, square and under roots as suggested by Gujarati (2012).

\subsubsection{Normality}

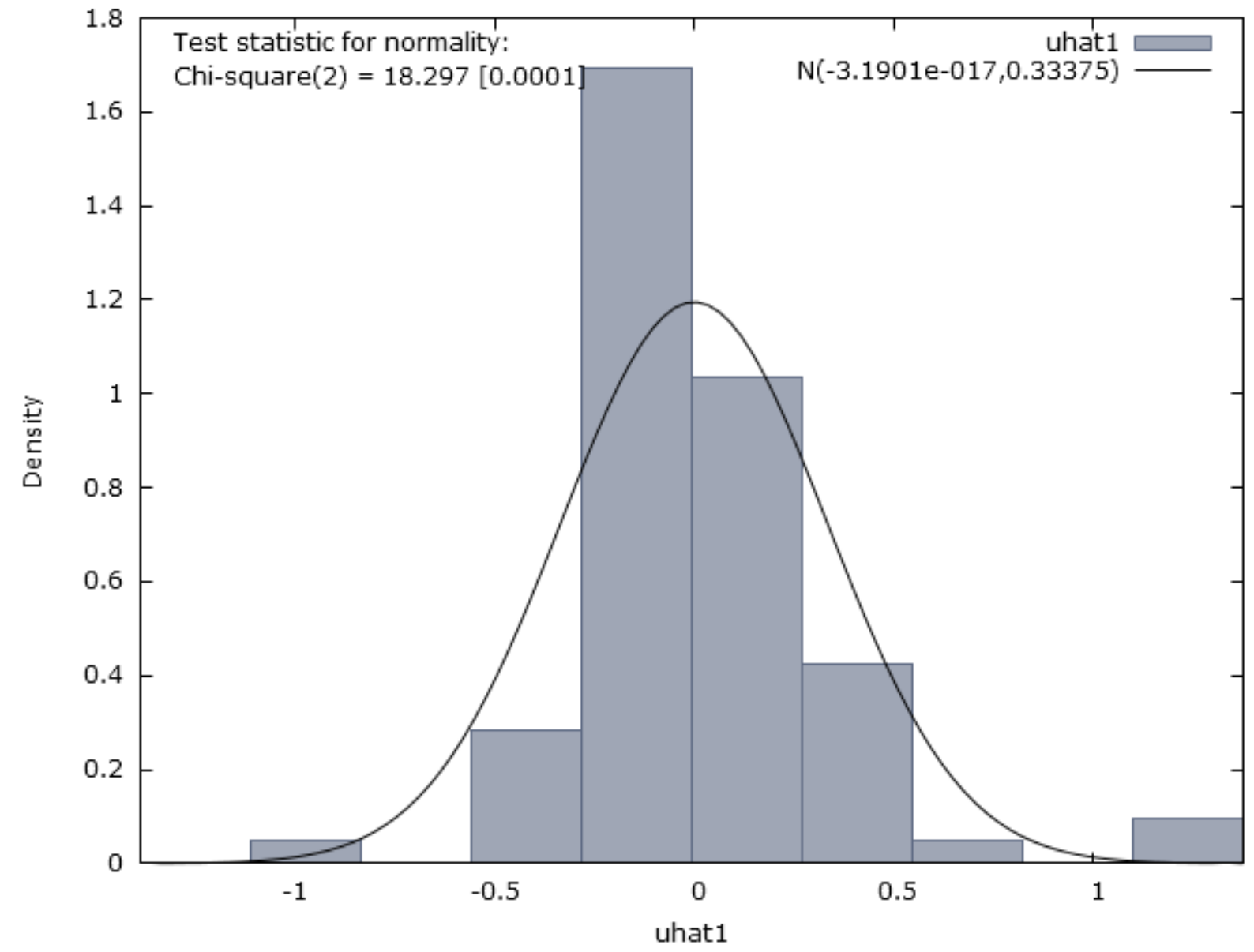

The figure shows that most of data is normal means comes in the bell shape.

\begin{tabular}{ccc}
\hline Test & Chi - square & p-value \\
\hline Normal distribution & 18.297 & 0.000249 \\
\hline
\end{tabular}

4.3 Descriptive Statistics

Table No 4.4: Descriptive statistic

\begin{tabular}{ccccccc}
\hline & Mean & Median & Mode & Minimum & Maximum & Standard Deviation \\
\hline LnMAAR & 0.20 & 0.10 & 0.05 & -1.10 & 1.38 & 0.38 \\
Age & 2.48 & 2.30 & 1.10 & 0.69 & 4.23 & 1.03 \\
Size & 6.01 & 5.62 & 5.01 & 4.03 & 9.00 & 1.19
\end{tabular}




$\begin{array}{lllllll}\text { Risk } & 0.11 & 0.03 & 0.00 & 0.00 & 1.03 & 0.24 \\ \text { UDR } & 0.53 & 1.00 & 1.00 & 0.00 & 1.00 & 0.50\end{array}$

This table show the descriptive statistics of variables both dependentvariables and independent. The variableisgiven as Market adjusted abnormal Return s (LnMAAR), Age of the firm (Age), Size of the firm (Size), IP0's Risk (Risk), Underwriter Reputation (UDR).

\subsection{Research Hypothesis Test}

Table 4.5: $\quad$ Result of Research Hypothesis Test

\begin{tabular}{lccc}
\hline Variables & Coefficient & T- Statistics & P-values \\
\hline Const & -0.113807 & -0.6555 & 0.5142 \\
Age & -0.127940 & -2.975 & 0.0040 \\
Size & 0.079 & 2.613 & 0.0109 \\
Risk & -0.011896 & -0.1289 & 0.8978 \\
UDR & 0.285 & 3.661 & 0.0005 \\
Adjusted R-squared & & 0.2141 & \\
F statistics & & 5.31035 & \\
Prob(F-Statistics) & & 0.000835 & \\
\hline
\end{tabular}

This table provides the result of regression model (pooled OLS estimator) the dependent variables in the model is Market adjusted abnormal Return $s$ (LNMAAR). The independent variables are given as Age of the firm (Age), Size of the firm (Size), IPO's Risk (Risk), Underwriter Reputation (UDR).

The data shows that coefficient of Age of the firm (Age) is equal to -0.127940 and its pvalue is equal to 0.0040. Thus, there is a negative relationship between Age of the firm and Market adjusted abnormal Return (LNMAAR) which means that if the age of the firm increase will decreasethe Market adjusted abnormal Return (LNMAAR) and the variables are significance because the error level is less than 5\%. The result also proved that the older firms have less ex-ante uncertainty as compared to the younger firms.The data shows that there is positive relationship between size of the firm and the Market adjusted abnormal Return (LNMAAR) which shows increase in the size of the firm will increase the Market adjusted abnormal Return (LNMAAR), as the coefficient of (Size) is 0.079 and P-value is 0.0109and show significance as the significant level is less than 5\%.The IPO Risk (Risk) show insignificance and negative relationship with Market adjusted abnormal Return(LNMAAR) as the significance level is more than 5\% and coefficient of (Risk) is -0.011896 and P-value is 0.8978respectively.The independent variable Underwriter Reputation (UDR) shows positive relationship with Market adjusted abnormal Return(LNMAAR) which mean increase in the size of the firm will increase the Market adjusted abnormal Return (LNMAAR) and with a P-value of 0.0005 and acoefficient of 0.285 and the data also indicate that there is significance relation as the significance level is less than 5\%.The value of Adjusted R square in the table 4.5 indicate thatthe explanatory variables explain $21.4 \%$ changes in the dependent variable (LNMAAR). 


\section{Conclusion}

The study has examined the short run performance of companies IPO's by selecting the sample of 77 companies listed on Pakistan stock exchange (PSX) from the period of 2000 to 2015 and the pertinent theories of IPO's underpricing in Pakistan. The short run performance is measured by using Market adjusted abnormal Return (MAAR). In this study data is shaped incross-sectional and Ordinary least square (OLS) method was selected to estimate regression model and to find the relationship between dependent variable and independent variables. This study found that Pakistani IPO's are significantly more underpriced in short run by $31.64 \%$ based on market adjusted abnormal return (MAAR). The result based on econometric models which indicated that in Pakistan the short run performance is significantly influenced by age of the firm, size of the firm, IPO's risk and underwriter reputation. Furthermore, A remarkable difference in the IPO's returns in different companies also identify the association between IPO's performance and its determinants. The finding shows that industrial setting in which company operates also highly effects the IPO's short run performances. Industries related result clarify that the industry concentrations and generosity show the information asymmetry at industry levels which later affect IPO's underpricing. The results strongly confirm the prediction of ex-ant uncertainty and signaling hypothesis of IPO's underpricing in Pakistan.

In this study Market Adjusted Abnormal Return (MAAR) is used as the only dependent variable and age of firm, size of firm, post IPO's risk and underwriter reputationas criteria to evaluate the short run performance IPO's in Pakistan. The result shows that there is negative and significant relationship between age of the firm and MAAR which indicate if the age of the firm increases the underpricing will be decrease while the size of the firm has positive and significant relation with the only dependent variable, Moreover Post IPO's risk shows negative association with Market Adjusted Abnormal Returns (MAAR) and the underwriter reputation shows positive relationship with the dependent variable. The adjusted R-Square explains the relationship between variables is $21.4 \%$.

\section{References}

Carter, R. B, \& Manaster, S. . (1990). Initial Public Offerings and Underwriter Reputation. Journal of Finance, 45, 1045-1067.

Faulhaber, Allen , \& F. and G. (1989). Signaling by Under-pricing in the IPO Market. Journal of Financial Economics, Vol. 23, 303-22.

Ibbotson , \& Roger. (1975). Price Performance of Common Stock New Issues. Journal of Financial Economics, 235-272.

Ibbotson, \& Roger. (1975). Price performance of common stock new issues. Journal of financial economics, 235-261. Ibbotson, Roger, Sindelar, J., \& Ritter, J. (1988). Initial Public Offering . Journal of Applid Corporate Finance, 37-45.

Ibbotson, Roger, Sindelar, J., \& Ritter, J. (1988). Initial Public Offerings. Journal of Applied Corporate Finance, 37-44.

Jegadeesh, Narasimhan, Weinstein, M., \& et, a. (1993). An Empirical Investigation of IPO Returns and Subsequent Equity Offerings. Journal of Financial Economics, 153-175. 
Kafayat, A., \& Farooqi, A. R. (2014). The Factors Affecting the Money Left on the Table by Pakistani IPO Issuers. AUDCE, 10, no. 4, 51-58.

Kafayat, A., \& Farooqi, A. R. (2014). The Factors Affecting the Money Left on the Table by Pakistani IPO Issuers. AUDE, Vol. 10, no. 4, 51-60.

Khan, S. (2017'). Aftermarket performance of initial public offering and its determinants in Pakistan. unpublished thesis Universiti Teknologi Malaysia.

Khan, S., \& Malik, F. (2016). Short run underpricing of initial public offering (IPO's): A conceptual review. Medwell journals, 842.

Khan, S., Anuar, M. A., \& et, a. (2016). Short run underpricing of initial public offering (IPO's): A conceptual review. Medwell Journals, 842-848.

Khan, S., Anuar, M. A., Malik, M. F., \& et, a. (2014). Short Run Underpricing of intial public offering (IPO's): a conceptual review. Medwell journals, 113-116.

Khan, S., Anuara, M. A., \& Malik, M. F. (2014). Review of Short Term and Long Term Performance of Initial Public Offering. Penerbit UTM Press. All rights reserved, 113116.

Kiymaz, \& H. (2000). The Initial and Aftermarket Performance of IPO's in an Emerging Market: Evidence from Istanbul Stock Exchange. Journal of Multinational

FinancialManagement , 10, 213-226a.

Loughran, T., \& Ritter, J. (1995). The new issues puzzle. Journal of Finance Vol. 50, 23 50.

M, M. Z., Smith, Z., \& Ahmad, M. (2016). An examination of short-run performance of IPOs using Extreme Bounds Analysis. Estudios de Economía, Vol. 43 - N ${ }^{o}$ 172, 74-75. Mcguinness, \& Paul. (1992). An Examination Of The Under-pricing of Initial Public Offerings in Hong Kong 1980-90. Journal of Business Finance and Accounting, issue 0306, 165-186.

Mumtaz, M. Z. (2017). An examination of short-run performance of IPO's using Extreme Bounds Analysis. Estudios de Economía, Vol. 43, 74.

Mumtaz, M. Z., \& et, a. (2016). An examination of short-run performance of IPO's using Extreme Bounds Analysis. Estudio de Economics vol. 43, 73.

Rock, \& K. (1986). Why New Issues are Underpriced. Journal of Financial Economics, 15, 187-212.

Sohail, M. K., \& Nasr, M. (2007). Performance of Initial Public Offerings in Pakistan. International Review of Business Research Papers Vol.3 No.2 June 2007, 421.

Sohail, M. K., \& Nasr, M. (2007). Performance of Initial Public Offerings in Pakistan. International Review of Business Research papers, 3(2), 420-436.

Sohail, Muhammad, \& Raheman, A. (2009). Determinants of Under-Pricing of IPOs Regarding Financial and non-financial Firms in Pakistan. European Journal of Economics, Finance and Administrative Sciences, ISSN 1450-2275, Issue 15.

Welch, \& I. (1989). Seasoned Offerings, Imitation Costs and the Under-pricing of Initial public offerings. Journal of Finance, 421-440.

Zubair, M., \& et, a. (2014). Determinants of Underpricing of Initial Public Offerings: Evidence from Pakistan. Journal of Business \& Economics Vol.6 No.1, 47-80. 